\title{
Comparison of the
}

Eosinophil Count to C reactive protein, Leukocyte Count, and Neutrophil Count for the detection of bacterial infection in ill-appearing children with fever admitted to the Emergency Department

BY ALKAN BAL, MURAT ANIL, GAMZE GÖKALP, YÜKSEL BICILIOGLU, AYŞE BERNA ANIL, FULYA KAMIT, NESLIHAN ZENGIN, MEHMET HELVACI

\section{Abstract}

Introduction. From late $19^{\text {th }}$ century to the present day, several authors have investigated the value of low eosinophil count as a biomarker of bacterial infection. In this study, we examined the value of eosinopenia for diagnosing bacterial infection in ill-appearing children admitted to the pediatric emergency department.

Methods. Retrospective review of the medical records of children age 1 month to 14 years who appeared ill on admission to the emergency department (ED). Data collected included; C-reactive protein (CRP) level leukocyte, neutrophil, eosinophil counts, results of microbiological tests, radiologic evaluation, and treatment given in the ED. Final outcome data were also collected. 
Results. In total, 878 met our case definition and inclusion criteria. 521 patients had confirmed or presumed bacterial infection and 355 patients had presumed or confirmed viral infection. Nineteen patients died; all had bacterial infections. Neutrophil, eosinophil counts and CRP level were independent risk factors for bacterial infection in the multivariate analysis $(p<0.05)$. The receiver operating characteristics (ROC) curves analysis for discriminating bacterial and viral infection showed that the eosinophil count ( $\leq 50$ cells $/ \mu \mathrm{L}$ ) (area under the ROC curve [AUROC] 0.671; 95\% Confidence Interval [CI]: 0.639-0.702) was similar to the neutrophil count (AUROC 0.655; 95\% CI: o,622-0.686), and CRP level (AUROC 0.710; 0.678-0.740) ( $p>0.05$ ). The sensitivities of the leukocyte, neutrophil, and eosinophil counts and CRP level were 57.5\%, 62.9\%, 61\%, and $57.1 \%$, respectively. The specificities of them were $59.1 \%, 63.3 \%, 67 \%$, and $77.4 \%$, respectively.

Conclusion. In our study population, although the accuracies of eosinophil, neutrophil counts, and CRP level were not enough, they had similar in distinguishing viral from bacterial infection in ill appearing febrile children. By comparison the leukocyte count had limited predictive value.

Key words: eosinopenia, CRP, acute phase reactants, childhood

\section{Introduction}

It is not always easy to differentiate between bacterial and viral infections in the emergency department. Many groups have searched for reliable markers to discriminate bacterial and viral infections. C-reactive protein (CRP) and the leukocyte and neutrophil counts are the acute-phase reactants used most widely in children admitted to the emergency department with a high fever. (1-3) In the last 20 years, procalcitonin has been identified as a promising bacterial infection marker in children with fever. Also, CD $15 \mathrm{~s}$ as a neutrophil surface molecule was reported a potentially valuable biomarker in infants with severe bacterial infection. (4) However, no perfect acute-phase reactant can differentiate between bacterial and viral infections with 100\% accuracy. (5-7) Furthermore, procalcitonin testing is very expensive and is seldom available in emergency departments in developing countries such as Turkey. (8)

In 1893, Zappert (9) first described marked reduction in the number of circulating eosinophils in acute infection, and it was utilized as a useful diagnostic sign during the first quarter of the last century. (10) After observing that eosinopenia is part of the normal response to stress, (11) it was assumed that the eosinopenia of acute infection is a secondary response to stress caused by the infection. (12) Since the 
early 2000s, eosinopenia has once again become a popular marker, although most studies have examined adult patients. $(8,13-15)$

It is not clear whether eosinopenia is a useful infection biomarker in children. Therefore, we want to compare the role of the eosinophil count to the roles of leukocyte count, neutrophil count, and serum CRP level for distinguishing between bacterial and viral infections in ill-appearing children with fever admitted to the emergency department.

\section{Materials and methods}

A retrospective analysis of pediatric patients admitted to the Pediatric Emergency Department of Tepecik Teaching and Research Hospital, Izmir, Turkey, from July 2011 to June 2013 was carried out. The Pediatric Emergency Department of Tepecik Teaching and Research Hospital is one of the most crowded emergency departments in Turkey, and is a pediatric emergency subspecialty-training clinic. The pediatric emergency department has got a 14-bed observation unit. We can monitor and give treatment to the some of the critical patients in the observation unit up to 23 hours. Then patients can be admitted to the hospital, if necessary. The laboratory tests of complete blood count and CRP are not performed routinely in all febrile children admitted to emergency department. These tests are usually done in children who are ill-appearing or have unstable vital signs, and when serious infection / inflammation is suspected. In our hospital, white blood cell (WBC) and eosinophil counts are determined using an automated analyzer (CELL-DYN $^{\circledR}$ 3700, Abbott, Germany). The plasma CRP concentration is measured by direct immunoturbidimetry (Olympus AU640 Chemistry Immuno Analyzer, Beckman Coulter, CA, USA).

During the study period, a total of 340044 patients were admitted to the pediatric emergency department. In cases older than one month, 69570 children had fever $\left(\geq 38^{\circ} \mathrm{C}\right.$ ) (figure 1). We defined the acutely ill febrile children $\left(\geq 38^{\circ} \mathrm{C}\right)$ older than one month as follows: In addition to fever $\geq 38.0^{\circ} \mathrm{C}$, there must be at least one of altered mental status, poor respiratory effort, respiratory distress, hypotension, poor peripheral perfusion, toxic appearing. Criteria for inclusion in our study included a case between one month and fourteen years of age, acutely ill febrile case $\left(\geq 38.0^{\circ} \mathrm{C}\right)$, the case with having the complete blood count and serum CRP measurement on admission. The exclusion criteria were (1) the children with insufficient data, (2) the children having a chronic disease or using drug, which could affect the number of blood eosinophil (3) the children with a different diagnosis from bacterial and viral infection (4) malignancies, (5) congenital or acquired immune disorders, (6) parasitic or fungal infections, (7) treatment with 
systemic steroids or antibiotics within 1 week of admission to the emergency department. We obtained and evaluated the data of patient's age, gender, and findings on history physical examination, results of all laboratory and radiologic tests, interventions, admission unit, and final outcome from the medical records. The information about patient's age, gender, final diagnosis, hospitalization status and length of hospital stay, mortality, CRP level, and leukocyte, neutrophil, and eosinophil counts were collected into a standard paper. The patients included the study were divided into two groups as the children with bacterial and viral infections according to their medical records. Bacterial infection in a patient was defined as the isolation of a significant pathogen or the patient with clinical, laboratory and radiological findings consistent with a bacterial infection according to the medical records. The patients with negative bacterial culture result and a positive test result for a viral antigen or clinical, laboratory and radiological findings consistent with a viral infection according to the medical records were allocated to the viral infection group. Prior to starting the study, we didn't create a diagnosis list. The authors decided the diagnoses when reviewing the medical records. Local ethic committee was approved the study.

The analyses were performed using SPSS 16.o (SPSS, Chicago, IL, USA). The data was transferred from the papers to SPSS. We used the chi-square test to compare proportions. The continuous variables were expressed as the mean \pm standard deviation (minimum-maximum). The Student-t test was used to compare two independent samples. Receiver operating characteristics (ROC) curves were constructed to predict bacterial infection. The best cut-off value was chosen using the Youden's index (the difference between the true positive rate and the false positive rate). (16) Maximizing this index allows to find, from the ROC curve, an optimal cut-off point independently from the prevalence. Multivariate analysis using logistic regression was performed to identify the independent risk factors for a diagnosis of bacterial infection. Differences were considered significant at $p<0.05$.

\section{Results}

In total, 876 children were included in the study. Of these, 546 (62.3\%) were hospitalized and 19 (2.2\%) died. The remainders were discharged from the observation unit after monitoring and receiving treatment as needed. The patients were classified into two groups according to their clinical diagnosis: 521 (59.5\%) patients were diagnosed with presumed or definitive bacterial infections (Group 1) and 355 (40.5\%) with presumed or definitive viral infections (Group 2). All of the patients with viral infection diagnosis have negative bacterial culture result. The Group 1 diagnoses included bacterial urinary tract infection (262 (50.3\%) patients 
with positive urine cultures), lobar pneumonia (110 (21.1\%) patients; 14 with positive blood cultures), bacterial sepsis (56 (10.7\%) patients with positive blood cultures), acute pyogenic meningitis [44 (8.4\%) patients, bacterial cerebrospinal fluid (CSF); 12 with positive cultures; in the remaining patients, the CSF findings were consistent with bacterial meningitis [CSF pleocytosis $\left(\geq 5 / \mathrm{mm}^{3}\right)$ with a predominance of neutrophils, elevated CSF proteins ( $\geq 100 \mathrm{mg} / \mathrm{dL}$ ), decreased CSF glucose ( $<40 \mathrm{mg} / \mathrm{dL}$ or $<50 \%$ serum glucose) (17)] , acute bacterial gastroenteritis (15 (2.9\%) patients with positive stool cultures), cellulitis (13 (2.6\%) patients, 1 patient with positive blood cultures; 12 patients not proven by culture), septic arthritis (11 (2.1\%) patients; 3 with positive bacterial joint fluid culture; in the remaining patients, the clinical and laboratory findings were consistent with septic arthritis), and osteomyelitis (10 (1.9\%) patients; 1 with positive blood cultures; in the remaining 9 patients, the clinical, laboratory and radiological findings were consistent with osteomyelitis). Group 2 included 151 (42.5\%) patients with clinically diagnosed acute bronchiolitis, 102 (28.7\%) with acute viral gastroenteritis ( 45 with stool positive for rotavirus antigen; 3 with stool positive for adenovirus antigen), 32 (9\%) diagnosed clinically with viral croup, 30 (8.5\%) diagnosed clinically with varicella, 25 (7\%) diagnosed clinically with viral exanthema, 13 (3.7\%) with infectious mononucleosis (typical clinical symptoms with positive serologic tests), and 2 (0.7\%) patients with presumed viral encephalitis. The rate of hospitalization, length of hospital stay, and the rate of death differed significantly between the groups $(p<0.05)$ (table 1$)$.

When we compare the laboratory parameters using student-t and chi-square tests, the leukocyte, neutrophil, and eosinophil counts, CRP level, the rate of leukocytosis ( $>15,000$ cells $/ \mu \mathrm{L})$, and the rate of the high neutrophil count (>10,00o cells $/ \mu \mathrm{L}$ ) were significantly different between the Group 1 and 2 $(\mathrm{p}<0.05)$. The variables found to be significantly different in the univariate analyses were included in a multivariate logistic regression analysis (the value of the Hosmer-Lemeshow statistic was 0.942). The neutrophil (p: 0.002; Odds ratio: 1.083; 95\%CI: 1.042-1.126) and eosinophil counts (p: o.o01; Odds ratio: 0.874; 95\%CI: 0.804-0.945) and CRP level (p<0.001; Odds ratio: 1.252; 95\%CI: 1.1631.348) were independent risk factors for bacterial infection in the multivariate analysis (table 2).

The ROC curve analysis for the discrimination of the cases with bacterial infection and the cases with viral infection showed that the eosinophil count (AUROC: o.671) was similar to the neutrophil count (AUROC: 0.655) and the CRP level (AUROC: 0.710), while all three differed significantly from the leukocyte count (eosinophil vs. CRP, $\mathrm{p}=0.0863$; eosinophil vs. neutrophil, $\mathrm{p}=0.4299$; eosinophil vs. leukocyte, $p=0.0050$; CRP vs. neutrophil, $p=0.0049$; CRP vs. leukocyte, 
$\mathrm{p} \leq 0.0001$; neutrophil vs. leukocyte, $\mathrm{p} \leq 0.0001)$. At a cutoff value of 50 cells $/ \mathrm{mm}^{3}$, eosinophil count yielded a sensitivity of $61 \%$ (neutrophil count: $62.9 \%$; CRP: $57.1 \%$ ), a specificity of $67 \%$ (neutrophil count: $63.3 \%$; CRP: $77.4 \%$ ), a positive predictive value of 73.1\% (neutrophil count: 71.6\%; CRP: 78.7\%), and a negative predictive value of 54\% (neutrophil count: 53.8\%; CRP: 55.2\%) (table 3).

\section{Discussion}

In this study, the effectiveness of eosinophil count in differentiating bacterial-viral infection was compared with leukocyte count, neutrophil count, and serum CRP measurement, one of very few studies done in children. $(18,19)$ We found that a low blood eosinophil count $\left(\leq 50\right.$ cells $\left./ \mathrm{mm}^{3}\right)$ is similar to a high CRP level $(\geq 1.22$ $\mathrm{mg} / \mathrm{dL}$ ) and a high neutrophil count ( $>5100$ cells $/ \mathrm{mm}^{3}$ ) for predicting bacterial infection in the pediatric emergency department. However, none of them had sufficient discriminatory power. Our work is the first study to investigate the eosinophil count in discrimination bacterial infections from viral infections in illappearing children admitted to the emergency department.

The upper limit of eosinophils in blood is 350 cells $/ \mathrm{mm}^{3}$ (1 $3 \%$ of peripheral blood leukocytes). (20) Increased levels of adrenal glucocorticosteroid and epinephrine are thought to cause the eosinopenia in acute infection (21). In addition, the decline in acute infection could be due to rapid peripheral sequestration and the migration of circulating eosinophils to the site of infection. $(9,21)$ The migration is mediated by the production of cytokines and chemotactic substances, such as $\mathrm{C}_{5} \mathrm{a}$ and fibrin fragments. (9) These are released into the bloodstream during acute inflammation. Bass (10) reported that eosinopenia is a response to the acute inflammatory process, rather than a response to a specific pathogen.

Montesanti et al. (11) showed that, during the course of infective pathologies in allergic children, there was an abrupt, significant reduction in circulating eosinophils followed by a return to control levels on remission. They also reported that the mean number of circulating eosinophils was $288 / \mathrm{mm}^{3}$ in healthy children, $46 / \mathrm{mm}^{3}$ in children in the acute phase of infection, and $252 / \mathrm{mm}^{3}$ in children during the remission phase. (12) Gil et al. (13) reported that

hyperleukocytosis $>10,000 / \mathrm{mm}^{3}$ and eosinophil counts $<40 / \mathrm{mm}^{3}$ were strongly related to bacterial infections in hospitalized adults. In a prospective study, eosinopenia ( $<40$ cells $/ \mathrm{mm}^{3}$ ) was a good diagnostic tool for distinguishing between non-infection and infection in the intensive care unit (ICU), while it was a moderate marker for discriminating between systemic inflammatory response 
syndrome and infection in newly admitted critically ill patients. (8) In that study, the AUROC was 0.89 for eosinophils and 0.77 for CRP for discriminating between non-infection and infection. Shaaban et al. (14) found that the AUROC for eosinopenia ( $<50$ cells $/ \mathrm{mm}^{3}$ ), high CRP $(>70 \mathrm{mg} / \mathrm{L})$, and high procalcitonin $(>1.5$ $\mu \mathrm{g} / \mathrm{L}$ ) for discriminating between non-infection and infection in the adult critical care unit were 0.72, 0.92, and 0.89, respectively. A case-control study conducted in Australia found that CRP, but not eosinopenia, was a significant predictor of bloodstream infection in a multivariate analysis in hospitalized adult patients. (15) Wibrow et al. (18) reported that CRP concentration and neutrophil count were better markers of bloodstream infection than eosinopenia $\left(<0.01 \times 10^{9} / \mathrm{mm}^{3}\right)$ in hospitalized pediatric and adult patients. Another study found no significant difference in the eosinophil count and percentage in children with and without infection in the pediatric ICU. (19) As seen above, the most important difference from literature is our work done in ill-appearing children in emergency department. Therefore, the comparing of our results with the literature is not easy. We determined that, the leukocyte and neutrophil counts and CRP level were higher, and the eosinophil count was lower, in children with bacterial infection at the time of emergency department admission. Nevertheless, the neutrophil and eosinophil counts and CRP level were significant predictors of bacterial infection in the multivariate analysis. Eosinophils at $\leq 50 / \mathrm{mm}^{3}$ had a sensitivity of $61 \%$, specificity of $67 \%$, positive predictive value (PPV) of $73.1 \%$, and negative predictive value (NPV) of $54 \%$ for discriminating between bacterial and viral infections. These results are similar to those for CRP and neutrophils. In our study, the sensitivity of CRP was low (57.1\%). The reasons can be listed as follows: first of all, CRP has got wide range of sensitivity in children with severe bacterial infection. (22,23) Secondly, CRP can rise both viral and bacterial infections. (24) Thirdly, it generally begins to increase after 12 hours of the fever onset. (24) Our study group consisted of ill-appearing children with bacterial and viral infection and $62.3 \%$ of them were hospitalized. In addition, we didn't evaluate the duration of fever. The AUROC of the leukocyte, neutrophil, and eosinophil counts and CRP level used to distinguish between children with bacterial and viral infections was $0.596,0.655,0.671$, and 0.710 , respectively. Our data demonstrated that eosinophil counts were significantly lower in ill-appearing children with bacterial infection diagnosis in emergency department. Although the predictive power of eosinophil count is not sufficient, it was similar to the CRP level and the neutrophil count and was better than the leukocyte count in predicting bacterial infection in ill-appearing children.

The limitations of this study should be considered. First, this study was conducted in a single pediatric emergency department. The information collected on patients was limited by its retrospective design. Clinical signs were not evaluated. The 
microbiologically documented infection rate was low. In bacterial infection group, the rate of microbiologically confirmed infection was $69.8 \%$. However, in viral infection group the rate of serologically confirmed infection was $16.3 \%$. None of the patients had undergone viral culture or PCR. The ill-appearing children in emergency department were included the study. Our sample had 60\% bacterial illness, $60 \%$ rate of hospitalization, and $2 \%$ rate of death. So this patient cohort was consisted of a large group of critically ill children. This is probably different from the pediatric emergency departments of developed countries. Finally, procalcitonin measurements were not included because this test has not been used routinely in our department until recently. This study has several strengths. The study sample was large and involved a diverse group of ill-appearing children with fever admitted to the emergency department. To the best of our knowledge, this is the first study to evaluate the value of eosinopenia as a market in illappearing children with fever admitted to the emergency department.

Taken together the literature, the data of our study and our clinical experiences, we consider that the number of eosinophil in peripheral blood is measured lower in bacterial infections or in severe infections. According to our data, the discriminant power of eosinophil count for bacterial and viral infection is similar to neutrophil count and serum CRP level and better than the leukocyte count. The beauty of this finding is hidden in easily obtaining from complete blood count. Unfortunately, the benefit of this laboratory parameters to the doctor in pediatric emergency department is not sufficient. We think that our data may be a starting point to identify the associations of eosinophil count with the risk of bacterial infections for ill-appearing children in emergency department. In the future, the prospective studies and the prediction models could further determine how eosinopenia may be helpful in the pediatric emergency department.

\section{References}

1. Nijman RG, Vergouwe Y, Thompson M, van Veen M, van Meurs AH, van der Lei J, et al. Clinical prediction model to aid emergency doctors managing febrile children at risk of serious bacterial infections: diagnostic study. BMJ 2013;346:f1706.

2. Bonsu BK, Chb M, Harper MB. Identifying febrile young infants with bacteremia: is the peripheral white blood cell count an accurate screen? Ann Emerg Med 2003;42:216-25.

3. Thompson M, Van den Bruel A, Verbakel J, Lakhanpaul M, Haj-Hassan T, Stevens $\mathrm{R}$, et al. Systematic review and validation of prediction rules for identifying children with serious infections in emergency departments and urgent-access primary care. Health Technol Assess 2012;16:1-100. 
4. Markic J, Jeroncic A, Polancec D, Bosnjak N, Markotic A, Mestrovic J, et al. CD15s is a potential biomarker of serious bacterial infection in infants admitted to hospital. Eur J Pediatr 2013; 172:1363- 9.

5. Gomez B, Bressan S, Mintegi S, Da Dalt L, Blazquez D, Olaciregui I, et al. Diagnostic value of procalcitonin in well-appearing young febrile infants. Pediatrics 2012 Nov;130 (5):815-22.

6. Ruiz-Alvarez MJ, García-Valdecasas S, De Pablo R, Sanchez García M, Coca C, Groeneveld TW, et al. Diagnostic efficacy and prognostic value of serum procalcitonin concentration in patients with suspected sepsis. J Intensive Care Med 2009; 24: 63-71.

7. Gilsdorf JR. $\underline{\text { C reactive protein and procalcitonin are helpful in diagnosis of }}$ serious bacterial infections in children. J Pediatrics 2012;60:173-4.

8. Abidi K, Khoudri I, Belayachi J, Madani N, Zekraoui A, Zeggwagh AA, et al. Eosinopenia is a reliable marker of sepsis on admission to medical intensive care units. Crit Care 2008;12:R59.

9. Bass DA. Reproduction of the eosinopenia of acute infection by passive transfer of a material obtained from inflammatory exudate. Infect Immun 1977;15:410-6.

10. Bass DA. Behavior of eosinophil leukocytes in acute inflammation. II. Eosinophil dynamics during acute inflammation. J Clin Invest 1975;56:870-9.

11. Montesanti M, Testa G, Biagi C, Bartolini F. Pattern of circulating eosinophils in allergic children suffering from infectious disease. Minerva Pediatr 1997;49:18791.

12. Montesanti M, Testa G, Biagi C, Bartolini F. Trend of circulating eosinophils in healthy children and children suffering from infectious diseases. A retrospective study. Minerva Pediatr 1997;49:179-86.

13. Gil H, Magy N, Mauny F, Dupond JL. Value of eosinopenia in inflammatory disorders: an "old” marker revisited. Rev Med Interne 2003;24:431-5.

14. Shaaban H, Daniel S, Sison R, Slim J, Perez G. Eosinopenia: Is it a good marker of sepsis in comparison to procalcitonin and C-reactive protein levels for patients admitted to a critical care unit in an urban hospital. J Crit Care 2010;25:570-5.

15. Ho KM, Towler SC. A comparison of eosinopenia and C-reactive protein as a marker of bloodstream infections in critically ill patients: a case control study. Anaesth Intensive Care 2009;37:450-6.

16. Kumar R, Indrayan A. Receiver operating characteristic (ROC) curve for medical researchers. Indian Pediatrics 2011;48:277-87.

17. Prober CG, Dyner L. Acute bacterial meningitis beyond the neonatal period. In: Kliegman RM, Stanton BF, St. Geme III JW, Schor NF, Behrman RE, editors. Nelson Textbook of Pediatrics.19 ${ }^{\text {th }}$ ed. Philadelphia: Elsevier Saunders; 2011. p. 2087-95.

18. Wibrow BA, Ho KM, Flexman JP, Keil AD, Kohrs DL. Eosinopenia as a diagnostic marker of bloodstream infection in hospitalised paediatric and adult patients: a 
case-control study. Anaesth Intensive Care 2011;39:224-30.

19. Kim YH, Park HB, Kim MJ, Kim HS, Lee HS, Han YK, et al. Prognostic usefulness of eosinopenia in the pediatric intensive care unit. J Korean Med Sci 2013;28:1149.

20. Rothenberg ME. Eosinophilia. N Engl J Med 1998;338:1592-600.

21. Bass DA, Gonwa TA, Szejda P, Cousart MS, DeChatelet LR, McCall CE.

Eosinopenia of acute infection: production of eosinopenia by chemotactic factors of acute inflammation. J Clin Invest 1980;65:1265-71.

22. Pulliam PN, Attia MW, Cronan KM. C-reactive protein in febrile children 1 to 36 months of age with clinically undetectable serious bacterial infection. Pediatrics 2001 Dec;108 (6):1275-9.

23. Isaacman DJ, Burke BL. Utility of the serum C-reactive protein for detection of occult bacterial infection in children. Arch Pediatr Adolesc Med 2002 Sep; 156 (9): 905-9. Erratum in: Arch Pediatr Adolesc Med 2003 Feb;157(2):208.

24. Peltola H, Jaakkola M. C-reactive protein in early detection of bacteremic versus viral infections in immunocompetent and compromised children. J Pediatr 1988 Oct;113(4):641-6.

Figure 1. Patients included and excluded from the study.

Table 1. Comparison of the clinical findings between presumed or definitive bacterial infection (Group 1) and presumed or definitive viral infection (Group 2).

\begin{tabular}{|c|c|c|c|c|}
\hline Parameters & $\begin{array}{l}\text { Total } \\
(n= \\
876)\end{array}$ & $\begin{array}{l}\text { Group } \\
1 \\
(\mathbf{n}= \\
521)\end{array}$ & $\begin{array}{l}\text { Group } \\
2 \\
(\mathbf{n}= \\
\mathbf{3 5 5})\end{array}$ & $\begin{array}{l}\mathbf{P} \\
\text { val } \\
\text { ue }\end{array}$ \\
\hline Age, month & $\begin{array}{l}38.7 \pm \\
14.3 \\
(1-174)\end{array}$ & $\begin{array}{l}44 \cdot 3 \pm 4 \cdot 6 \\
(1-174)\end{array}$ & $\begin{array}{l}27.1 \pm 0.8 \\
(1-170)\end{array}$ & $0.526^{1}$ \\
\hline Gender, n (\%) & $\begin{array}{l}481 \\
(54.9)\end{array}$ & $\begin{array}{l}272 \\
(52.3)\end{array}$ & $\begin{array}{l}209 \\
(58.9)\end{array}$ & \\
\hline Female & $\begin{array}{l}395 \\
(45.1)\end{array}$ & $\begin{array}{l}249 \\
(47 \cdot 3)\end{array}$ & $\begin{array}{l}146 \\
(41.1)\end{array}$ & $0.05^{11}$ \\
\hline Hospitalized, n (\%) & $\begin{array}{l}546 \\
(62.3)\end{array}$ & $\begin{array}{l}387 \\
(74.2)\end{array}$ & $\begin{array}{l}159 \\
(44 \cdot 7)\end{array}$ & $0.001^{11}$ \\
\hline $\begin{array}{l}\text { Length of hospital stay, } \\
\text { days }\end{array}$ & $\begin{array}{l}7.5 \pm 0.2 \\
(3-28)\end{array}$ & $\begin{array}{l}8 \pm 0.4 \\
(5-28)\end{array}$ & $\begin{array}{l}6 \pm 0.3 \\
(3-8)\end{array}$ & $0.001^{1}$ \\
\hline
\end{tabular}


Died, n (\%)

$19(2.2) \quad 19(3.6) \quad 0$

$0.001^{11}$

Data are expressed as the mean \pm standard deviation (minimum-maximum) or $\mathrm{n}$ (\%).

${ }^{1}$ Student-t test; ${ }^{11}$ Chi-square test.

Table 2. Comparison of the laboratory findings between presumed or definitive bacterial infection (Group 1) and presumed or definitive viral infection (Group 2), and logistic regression analysis for Group 1.

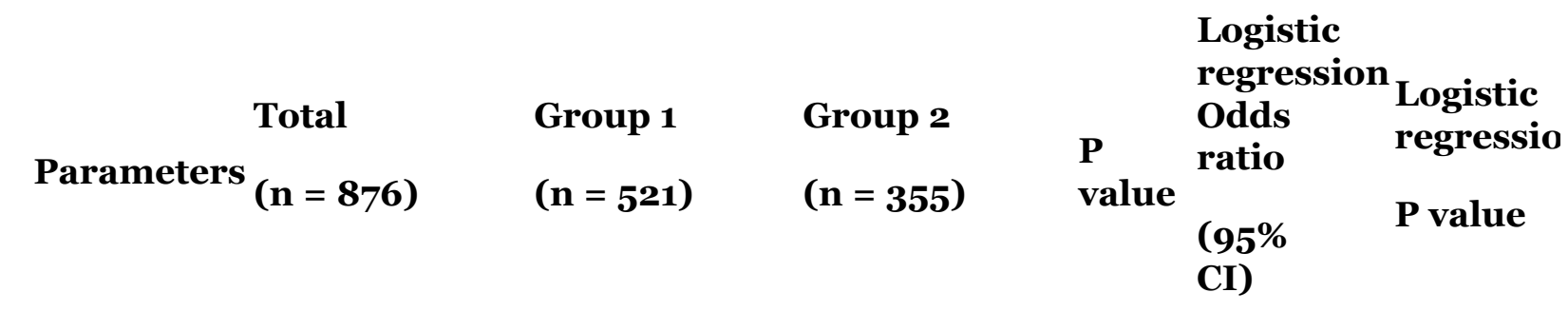

Leukocytes

$12,772.8 \pm 4,990.013,567.1 \pm 6,975.611,783.6 \pm 4,859.0$

$\begin{array}{llllll}(\text { cells } / & (1,030- & (1,500- & (1,030- & <0.001- & \text { NS } \\ \mu \mathrm{L})^{*} & 52,700) & 52,700) & 28,200) & \end{array}$

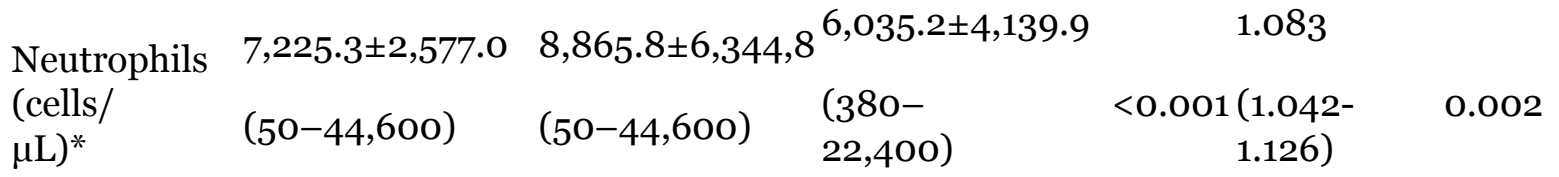

\begin{tabular}{|c|c|c|c|c|c|}
\hline CRP & $16 \pm 7$ & $47 \pm 7$ & $11 \pm 6$ & 1.252 & \\
\hline$(\mathrm{mg} / \mathrm{L})^{*}$ & $(1-549)$ & $(1-549)$ & $(1-123)$ & $\begin{array}{r}<0.001\left(1.163^{-}\right. \\
1.348)\end{array}$ & $<0.001$ \\
\hline
\end{tabular}

$\begin{array}{lccccc}\begin{array}{l}\text { Eosinophils } \\ \text { (cells/ }\end{array} & 107.2 \pm 27.6 & 78.3 \pm 22.1 & 151.8 \pm 22.5 & 0.874 \\ \mu \mathrm{L})^{*} & (0-1,500) & (0-1,500) & (0-1,400) & <0.001(0.804- & 0.001\end{array}$

Leukocytes

\begin{tabular}{|c|c|c|c|c|}
\hline $\begin{array}{l}<5,000 \\
\text { cells/ } / \mu \mathrm{L} \\
(+)^{* * *}\end{array}$ & $35(3.9 \%)$ & $26(4.9 \%)$ & $9(2.5 \%)$ & 0.069 \\
\hline
\end{tabular}

Leukocytes

$>15,000$

cells $/ \mu \mathrm{L}$

$219(25 \%)$

$163(31.2 \%)$

$56(15 \cdot 7 \%)$

$<0.001-$ 
Neutrophils

\begin{tabular}{|c|c|c|c|c|}
\hline $\begin{array}{l}<1,500 \\
\text { cells/ } / \mu \mathrm{L} \\
(+)^{* *}\end{array}$ & $31(3.5 \%)$ & $20(3.8 \%)$ & $11(3 \%)$ & 0.560 \\
\hline
\end{tabular}

Neutrophils

$>10,000$

cells $/ \mu \mathrm{L}$

$193(22 \%)$

$155(29.7 \%)$

$38(10.7 \%)$

$<0.001-$

NS $(+)^{* *}$

${ }^{*}$ mean \pm standard deviation (minimum-maximum); ${ }^{* *} \mathrm{n}(\%) \mathrm{CI}$, Confidence interval; CRP, C-reactive protein; NI, Not included; NS, Nonsignificant.

Table 3. The receiver operating characteristics curve analysis of the leukocyte, neutrophil, and eosinophil counts, and CRP level for diagnosing bacterial infection.

\section{Parameters Cutoff Sensitivity Specificity PPV NPV AUROC}

\begin{tabular}{|c|c|c|c|c|c|}
\hline $\begin{array}{l}\text { Leukocytes } \\
\text { (cells } / \mu \mathrm{L})\end{array}$ & $>10,80$ & 57.5 & 59.1 & 66.248 .5 & $\begin{array}{l}0.596 \\
(0.563- \\
0.629)\end{array}$ \\
\hline $\begin{array}{l}\text { Neutrophils } \\
\text { (cells } / \mu \mathrm{L})\end{array}$ & $>5,100$ & 62.9 & 63.3 & 71.653 .8 & $\begin{array}{l}0.655 \\
(0.622- \\
0.686)\end{array}$ \\
\hline $\begin{array}{l}\text { Eosinophils } \\
(\text { cells } / \mu \mathrm{L})\end{array}$ & $\leq 50$ & 61 & 67 & 73.154 & $\begin{array}{l}0.671 \\
(0.639- \\
0.702)\end{array}$ \\
\hline $\mathrm{CRP}(\mathrm{mg} / \mathrm{dL})$ & $\begin{array}{l}\geq \\
1.22\end{array}$ & 57.1 & 77.4 & 78.755 .2 & $\begin{array}{l}0.710 \\
(0.678- \\
0.740)\end{array}$ \\
\hline
\end{tabular}

AUROC, area under the receiver operating characteristic curve; CRP, C-reactive protein; NPV, negative predictive value; PPV, positive predictive value.

Corresponding author:

Alkan Bal

Pediatric Emergency Department

Izmir Tepecik Training and Research Hospital

Tepecik Eğitim ve Araştırma Hastanesi Gaziler st, Yenişehir, 35170 Konak, Izmir, Turkiye

Phone: +90 2324696969

Fax: +90 2324330756

E-mail: balalkan@hotmail.com 
Article printed from Signa Vitae: http://www.signavitae.com

URL to article: http://www.signavitae.com/2015/12/comparison-of-theeosinophil-count-to-c-reactive-protein-leukocyte-count-andneutrophil-count-for-the-detection-of-bacterial-infection-in-illappearing-children-with-fever-admitted-to-the-emergenc/

Copyright (C) 2015 Signa Vitae. All rights reserved. 